\title{
The study of urban track transportation environmental noise and vibration prevention: floating slab track of Taipei MRT
}

\author{
S. Chang ${ }^{1,2}$, K. Y. Chang ${ }^{1} \&$ K. H. Cheng ${ }^{3}$ \\ ${ }^{1}$ Technology Department of Civil Engineering, \\ National Taipei University of Technology, Taiwan, ROC \\ ${ }^{2}$ CECI Engineering Consultants, Inc., Taiwan, ROC \\ ${ }^{3}$ DORTS, T.C.G., Taiwan, ROC
}

\begin{abstract}
Population density and traffic jams are common phenomena in modern society. Although roadway areas increase every year, traffic congestion still cannot be solved effectively. So land transportation is turning to track transportation. Track transportation has many advantages, but the noise and vibration induced from the wheel/rail contact are sensitive issues to the neighbouring residents along the line in the urban areas. Much complaint about noise and vibration arose from the residents along the Taipei MRT lines where the MRT tunnels were underneath the buildings, so Floating Slab Track (FST), one of the best solutions of noise and vibration prevention in the track engineering, was applied to the Taipei MRT.

This paper studies the overall issues of the FST based on the localized consideration in the planning, design, construction, final noise and vibration performance measurement stages, including the mode of structure analyses, vibration isolating component, material, localize geotechnical parameters, type of structure, rail fastener, elastic coefficient, vibration isolating component, the actually performance of noise and vibration deduction, etc. We hope we can share our practical experience of the noise and vibration prevention/environmental pollution prevention in urban transportation to other railway systems or with academics in the environment and railway fields in other part of the world.
\end{abstract}

Keywords: vibration, localize, floating slab track, vibration prevention, elastic coefficient. 


\section{Foreword}

Population density and traffic impact are common phenomena in modern society in Taiwan. Such problems are getting worse with the passing of time. Although roadway areas increase every year, traffic jam still cannot be solved effectively. So land transportation is turning to track transportation. However, there is a lot of complaint about the noise and the vibration caused by the operation of the Taipei MRT Zhonghe line. The noise and vibration problems are caused by the friction and impact via the wheel/rail contact. This vibration effectively propagates through the ground to the neighbouring buildings along the line, which have secondary noise or damage to sensitive equipment. The railway will solve the noise and vibration problems through track/ train/ geology/ structure. The solution of the track was elastic rail fasteners, elastic rail boots, elastic trackbed (FST, LVT, rubber boot tie). Most of the Xinzhung-Luzhou line runs beneath the existing buildings. Thus the FST was adopted to solve those problems.

This paper provides the results of the study for the floating slab to be used in Taiwan and the studies of overall issues of the FST based on the localized consideration in Taipei MRT. The study includes the mode of structure analyses, vibration isolating component, material, localized geotechnical parameters, types of tunnel, rail fastener, elastic coefficient, vibration isolating component, the actual performance of noise and vibration deduction, etc. Finally, we try to verify this study so we make a site measurement and test. We hope to share our experience and the results of the study and the reference data bank for the vibration prevention on the track of the urban transportation and for environmental pollution prevention to other railway systems or to academia with interests in the environment and railway fields in other parts of the world.

\section{The source of track vibration}

The vibration of track was caused by the railroad trains running on the track due to the following reasons (see Figure 1).

(1) Wheel roughness

(2) Rail corrugation

(3) Wheel and rail grinding abrasion metal chipping.

(4) Discontinuous rail (Taipei MRT do not have the rail expansion join)

(5) Unsmooth of the track supporting structure (stiffness).

The above-mentioned reasons will cause track vibration, and this source of the vibration will use the following way to the adjacent buildings.

(1) Track system

(2) Tunnel structure

(3) Geotechnical conditions

(4) Residential structure foundation.

Different types of structure will direct effect on the vibration measuring value inside the adjacent buildings along the MRT routes 


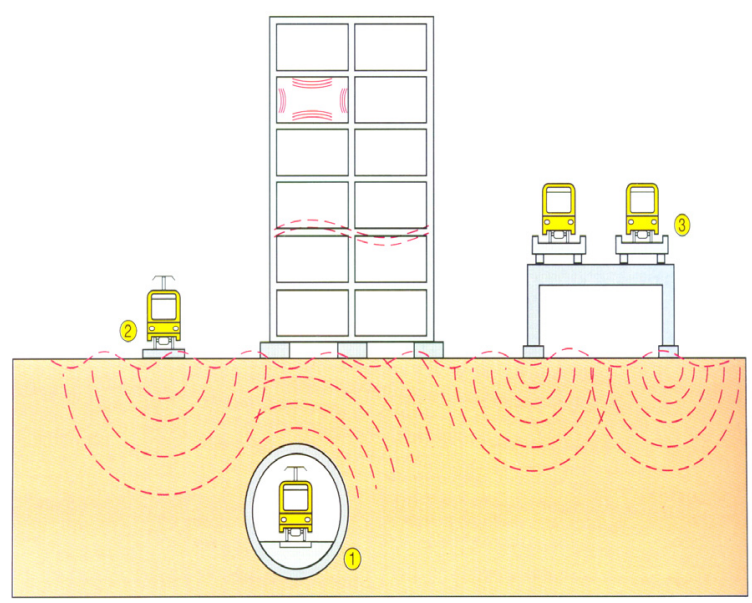

Figure 1: $\quad$ Track ground-borne vibration propagation route (GERB).

\section{Types of floating slab track}

The theory of FST was the mass (the mass of the track and concrete slab) and spring (isolating/deduction of vibration) system. The floating slab track was totally insulated from the civil structure. It insulated the vibration from the train via the spring. The FST can be divided into two categories - the ballast FST and the non-ballast FST. And it can be further categorized into continuous FST, semi-continuous FST, and miniature FST. Furthermore, according to the spring method, they can also be categorized into mechanically bearing FST or rubber bearing FST.

\subsection{Ballast floating slab track}

Ballast FST is made of a U-shaped concrete slab with ballast and track, becoming the ballast track. An elastic support system for vibration-reduction

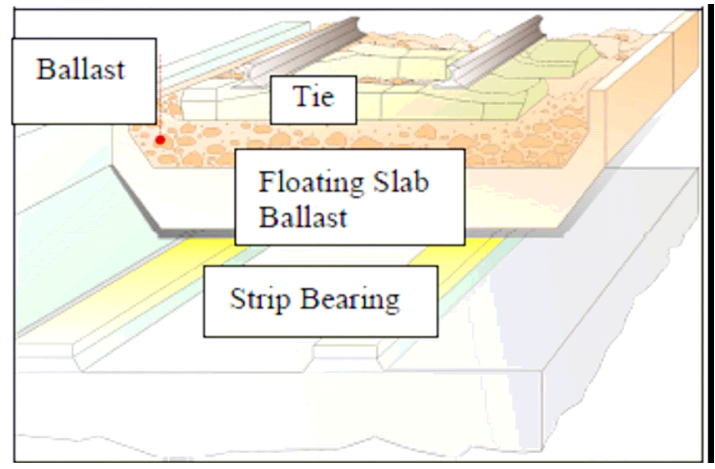

Figure 2: $\quad$ Ballast floating slab track. 
isolation was inserted between the U-shaped trough concrete slab and the civil structure (see Figure 2). The continuous floating slab was first been adopted in England. The slab uses the radiated damping from the plate bending waves to divert the energy excited from the resonant frequency (at $15-18 \mathrm{~Hz}$ ).

\subsection{Non-ballast floating slab track}

The non-ballast FST mostly consists of concrete slabs with non ballasted track and elastic bearing sitting on the civil structure (see Figure 3).

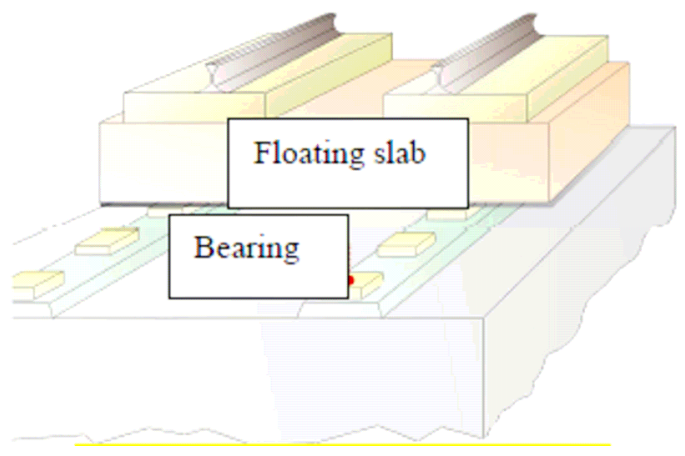

Figure 3: Non-ballast floating slab track.

\section{The evaluation of FST on Taipei MRT system}

The vibration was transmitted through the track, the tunnel/viaduct and the soil. The vibration will be reduced due to the distance attenuation loses (including geometry attenuation and soil couple loss/ soil layer interior damping), and the building structure transmission. It does not threaten building safety. For example, the wheel/rail short-distance vibration is 70 decibels, converts the acceleration is $0.0316 \mathrm{~m} / \mathrm{s}^{2}$, equalling to the earthquake knock rating 2 magnitude. The biggest vibration value measured in the private residences along the Taipei MRT routes was $0.0015 \mathrm{~m} / \mathrm{s}^{2}$. It was equal to the earthquake knock rating 0 magnitude and did not cause any safety problem to the buildings. The FST should have an overall consideration to get an appropriate nature frequency to avoid the resonance among the car body and the track (its nature frequency was within 5-150 Hz), and the civil structure and soil propagation, and the adjacent buildings (the soil propagation frequency rang was $25-150 \mathrm{~Hz}$, different parts of car body was 1$60 \mathrm{~Hz}$ ). We make static and dynamic analyses in the FST design, the one car length vibration analysis model (see Fig. 4), Car mass $\mathrm{M}_{c}$, Primary suspension stiffness $\mathrm{K}_{\mathrm{s} 1}$ Damping ratio $\mathrm{C}_{\mathrm{s} 1}$, Bogie mass $\mathrm{M}_{\mathrm{t}}$, Secondary suspension stiffness $\mathrm{K}_{\mathrm{s} 2}$ Damping ratio $\mathrm{C}_{\mathrm{s} 2}$, Wheel load $\mathrm{M}_{\mathrm{w}}$, the dynamic loading to the track $\mathrm{P}_{1}(\mathrm{t}), \mathrm{P}_{2}$ (t), $\mathrm{P}_{3}(\mathrm{t}), \mathrm{P}_{4}(\mathrm{t})$, and the simple pattern (see Fig. 5). 


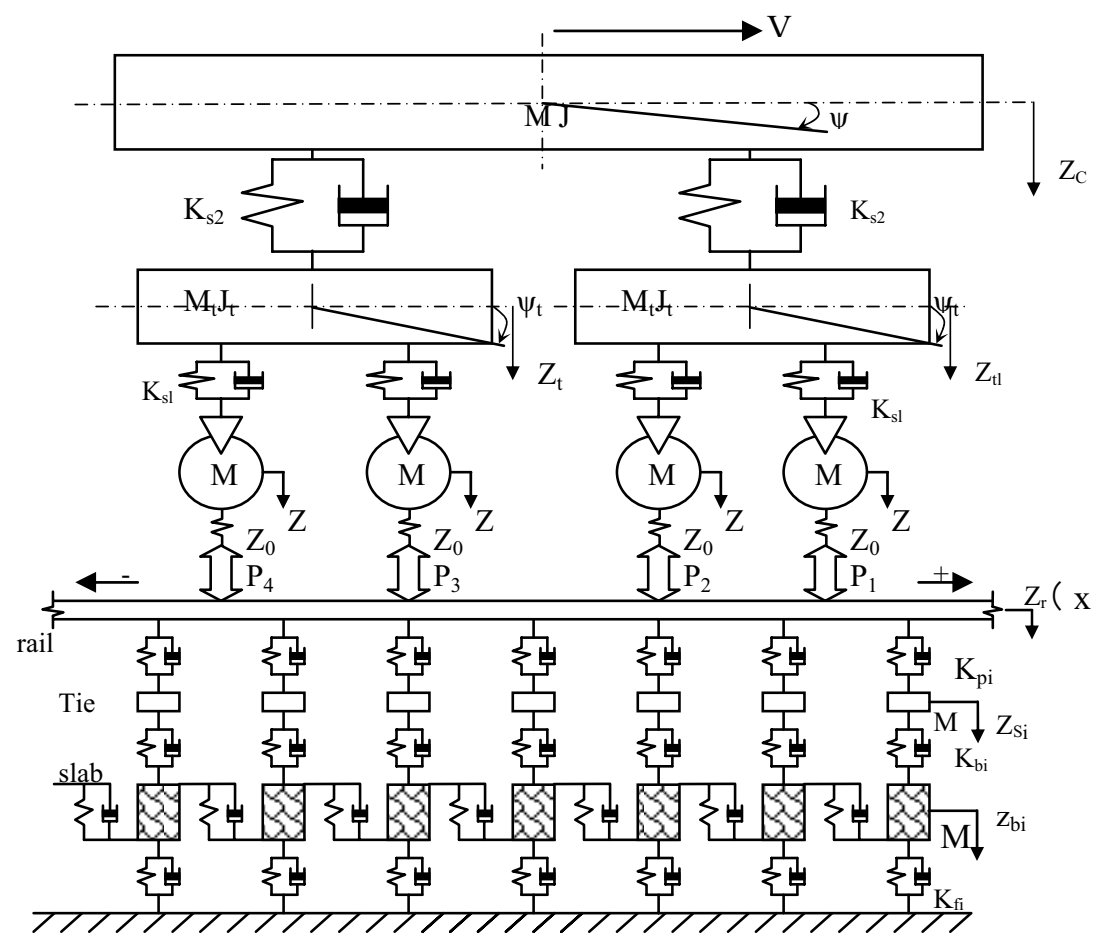

Figure 4: The vertical coupling model of wheel/track.

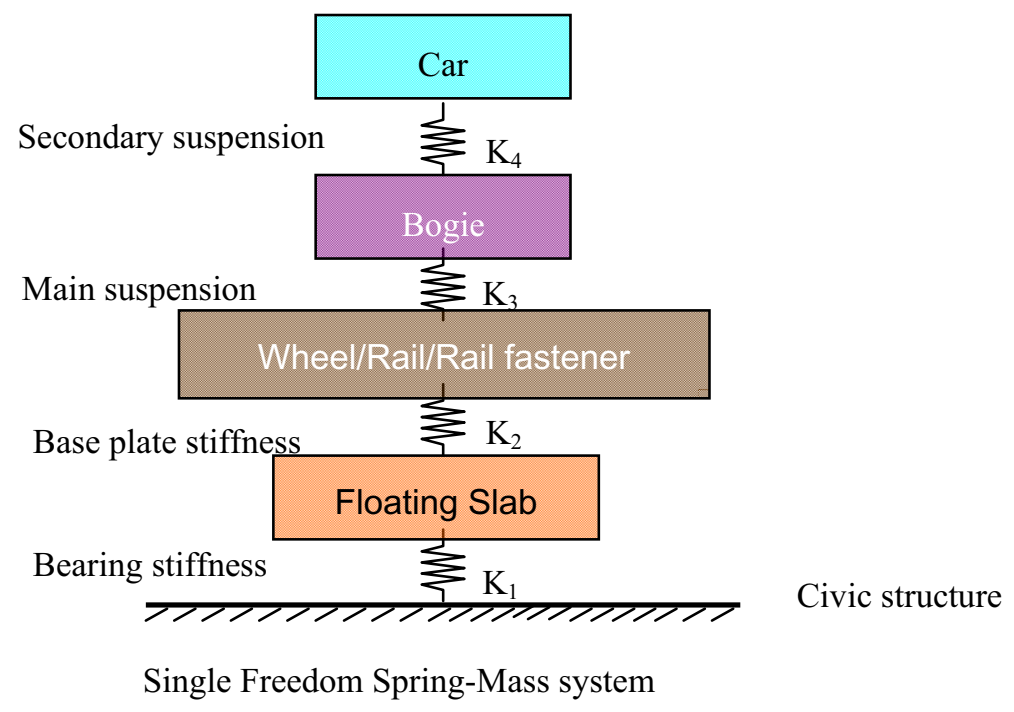

Figure 5: The simple model of wheel/track. 
We have studied a simple model calculation by ABAQUS and the result is as follows:

Case 1

Rail base plate mass $=2144 \mathrm{~kg} \quad$ Elastic coefficient $=25 \mathrm{KN} / \mathrm{mm} * 8=200 \mathrm{KN} / \mathrm{mm}$. FST $/$ Bearing mass $=5163 \mathrm{~kg}$ Elastic coefficient $=8 \mathrm{KN} / \mathrm{mm}^{*} 8=64 \mathrm{KN} / \mathrm{mm}$.

Table 1.

\begin{tabular}{|c|c|c|c|}
\hline & Mass $(\mathrm{kg})$ & $\begin{array}{c}\text { Elastic coefficient } \\
(\mathrm{KN} / \mathrm{mm})\end{array}$ & $\begin{array}{c}\text { Nature Frequency } \\
(\mathrm{Hz})\end{array}$ \\
\hline $\begin{array}{c}\text { bearing pad } / \mathrm{FST} \\
\left(\mathrm{M}_{1}, \mathrm{~K}_{1}\right)\end{array}$ & 5163 & 64 & 15.052 \\
\hline $\begin{array}{c}\text { Rail base plate } \\
\left(\mathrm{M}_{2}, \mathrm{~K}_{2}\right)\end{array}$ & 2144 & 200 & 58.853 \\
\hline $\begin{array}{c}\text { Primary suspension system } \\
\left(\mathrm{M}_{3}, \mathrm{~K}_{3}\right)\end{array}$ & 5847 & 2.67 & 3.692 \\
\hline $\begin{array}{c}\text { Secondary suspension system } \\
\left(\mathrm{M}_{4}, \mathrm{~K}_{4}\right)\end{array}$ & 12250 & 0.57 & 0.972 \\
\hline
\end{tabular}

Case 2

Rail base plate mass $=2900 \mathrm{~kg}$ Elastic coefficient $=25 \mathrm{kN} / \mathrm{mm} * 20=500 \mathrm{KN} / \mathrm{mm}$. FST $/$ Bearing mass $=26710 \mathrm{~kg}$ Elastic coefficient $=8 \mathrm{KN} / \mathrm{mm} * 20=160 \mathrm{KN} / \mathrm{mm}$.

Table 2 .

\begin{tabular}{|c|c|c|c|}
\hline & Mass (kg) & $\begin{array}{c}\text { Elastic } \\
\text { coefficient } \\
(\mathrm{KN} / \mathrm{mm})\end{array}$ & $\begin{array}{c}\text { Nature } \\
\text { Frequency }(\mathrm{Hz})\end{array}$ \\
\hline $\begin{array}{c}\mathrm{FST} / \text { Bearing } \\
\left(\mathrm{M}_{1}, \mathrm{~K}_{1}\right)\end{array}$ & 26710 & 160 & 11.793 \\
\hline $\begin{array}{c}\text { Rail base plate } \\
\left(\mathrm{M}_{2}, \mathrm{~K}_{2}\right)\end{array}$ & 2900 & 500 & 69.841 \\
\hline $\begin{array}{c}\text { Primary suspension } \\
\text { system }\left(\mathrm{M}_{3}, \mathrm{~K}_{3}\right)\end{array}$ & 5847 & 2.67 & 3.741 \\
\hline $\begin{array}{c}\text { Secondary } \\
\text { suspension } \\
\text { system }\left(\mathrm{M}_{4}, \mathrm{~K}_{4}\right)\end{array}$ & 12250 & 0.57 & 0.976 \\
\hline
\end{tabular}

Case 3

Rail base plate Mass $=2013 \mathrm{~kg}$ elastic coefficient $=25 \mathrm{KN} / \mathrm{mm} * 8=200 \mathrm{KN} / \mathrm{mm}$. FST $/$ Bearing Mass $=5032 \mathrm{~kg}$ Elastic coefficient $=10 \mathrm{KN} / \mathrm{mm}^{*} 8=80 \mathrm{KN} / \mathrm{mm}$.

The dynamic moving load analyses get the conclusion that the mini FST has a good vibration deduction at $2-10 \mathrm{~Hz}$, the vibration level from the central line of track to the different location of $5 \mathrm{~m}$ and $10 \mathrm{~m}$ was $10 \mathrm{~dB}$ depending on the local geology condition. 
Table 3.

\begin{tabular}{|c|c|c|c|}
\hline & $\begin{array}{c}\text { Mass } \\
(\mathrm{kg})\end{array}$ & $\begin{array}{c}\text { Elastic } \\
\text { coefficient } \\
(\mathrm{KN} / \mathrm{mm})\end{array}$ & $\begin{array}{c}\text { Nature } \\
\text { Frequency }(\mathrm{Hz})\end{array}$ \\
\hline FST/Bearing $\left(\mathrm{M}_{1}, \mathrm{~K}_{1}\right)$ & 5,032 & 80 & 17.014 \\
\hline $\begin{array}{c}\text { Rail base plate } \\
\left(\mathrm{M}_{2}, \mathrm{~K}_{2}\right)\end{array}$ & 2013 & 200 & 60.587 \\
\hline $\begin{array}{c}\text { Primary suspension } \\
\text { system }\left(\mathrm{M}_{3}, \mathrm{~K}_{3}\right)\end{array}$ & 5847 & 2.67 & 3.705 \\
\hline $\begin{array}{c}\text { Secondary suspension } \\
\text { system }\left(\mathrm{M}_{4}, \mathrm{~K}_{4}\right)\end{array}$ & 12250 & 0.57 & 0.973 \\
\hline
\end{tabular}

Three methods of evaluation were adopted: The mathematical analysis, the numerical analysis and the experience formula. Here we use the experience formula of the Taipei MRT. The method of the Taipei MRT is the experience formula which was revised from the previous application of overseas cases used by DORTS' consultants, so as to get an optimal application for the Taipei MRT.

\subsection{The basic condition of the evaluation /forecast}

The basic condition: The twin tunnel, the distance between the track centreline and building is 10 meter, six car units with speed $65 \mathrm{~km} / \mathrm{h}$, calculate vibration datum value, then the following factors are taken into consideration as to revise this datum value:

- Track bed and track pattern corrected value

- The distance corrected value

- The building structure category discount value

- The building height discount value

- The ground born vibration transform to the ground born noise

- Track anti-vibration and vibration insulation method

The noise and vibration quantity of two trains must be calculated separately at identical place, then both values should be summed up by the logarithm calculation.

The noise and vibration of train operation along the MRT routes will basically follow up the evaluation formulate in the FE-31 report. The FST will be used in the Xinzhuang-Louzhou line and Taipei MRT future network. 


\section{Expected results}

The forecast of FST vibration isolation have two ways: one is actual measurement, and the other is theoretical calculation. Using the theory to forecast the FST anti-vibration effect, the information of the characteristic frequency $\left(\mathrm{F}_{\mathrm{c}}\right)$ of the car and the track should be known. The current $\mathrm{F}_{\mathrm{c}}$ of couple car (DM1 or M2) at the Danshui line is summarized as Table 6.

Table 4: $\quad$ The characteristic frequency and the car mass at the Danshui line.

\begin{tabular}{|c|c|c|c|c|}
\hline item & W1 & W2 & W3 & W4 \\
\hline Mass of car ( $\mathrm{kg})$ & 39500 & 43100 & 58640 & 61700 \\
\hline Mass of bogie ( $\mathrm{kg}$ ) & 7500 & 7500 & 7500 & 7500 \\
\hline Un-sprung mass of bogie- $10 \%$ of design axle load $(\mathrm{kg})$ & 1653 & 1653 & 1653 & 1653 \\
\hline The mass of main suspension system of bogie $(\mathrm{kg})$ & 5847 & 5847 & 5847 & 5847 \\
\hline The mass of secondary suspension system of bogie ( $\mathrm{kg}$ ) & 12250 & 14050 & 21820 & 23350 \\
\hline $\begin{array}{l}\text { The vertical elastic coefficient of main suspension system of } \\
\qquad \text { bogie }(\mathrm{KN} / \mathrm{mm})\end{array}$ & 2.6712 & 2.7376 & 3.2728 & 3.372 \\
\hline $\begin{array}{l}\text { The vertical nature frequency of main suspension system of } \\
\text { bogie }(\mathrm{Hz})\end{array}$ & 3.40 & 3.44 & 3.77 & 3.82 \\
\hline $\begin{array}{l}\text { The vertical elastic coefficient of secondary suspension } \\
\text { system of bogie ( } \mathrm{KN} / \mathrm{mm})\end{array}$ & 0.570 & 0.634 & 0.834 & 0.860 \\
\hline $\begin{array}{l}\text { The vertical nature frequency of secondary suspension } \\
\text { system of bogie }(\mathrm{Hz})\end{array}$ & 1.086 & 1.069 & 0.984 & 0.966 \\
\hline
\end{tabular}

Table 5: The summary of nature frequency of track on the Taipei MRT.

\begin{tabular}{|c|c|c|c|c|c|c|}
\hline $\begin{array}{c}\text { Track system ( Rail base- } \\
\text { plate ) }\end{array}$ & $\begin{array}{c}\text { No } \\
\text { car } \\
\text { load }\end{array}$ & $\begin{array}{c}\text { Under W1 } \\
\text { load at } \\
\text { DM1/M2 } \\
\text { car }\end{array}$ & $\begin{array}{c}\text { Under W2 } \\
\text { load at } \\
\text { DM1/M2 } \\
\text { car }\end{array}$ & $\begin{array}{c}\text { Under W3 } \\
\text { load at } \\
\text { DM1/M2 } \\
\text { car }\end{array}$ & $\begin{array}{c}\text { Under W4 } \\
\text { load at } \\
\text { DM1/M2 } \\
\text { car }\end{array}$ & Remarks \\
\hline $\begin{array}{c}\mathrm{DF} \text { track } \\
\text { K }=20.38 \mathrm{KN} / \mathrm{mm}\end{array}$ & - & 45.67 & 45.68 & 45.75 & 45.76 & $\begin{array}{c}\text { elevated } \\
\text { section }\end{array}$ \\
\hline $\begin{array}{c}\mathrm{DF} \text { track / } \\
\mathrm{K}=15.76 \mathrm{KN} / \mathrm{mm})\end{array}$ & - & 40.25 & 40.27 & 40.35 & 40.37 & $\begin{array}{c}\text { underground } \\
\text { section }\end{array}$ \\
\hline $\begin{array}{c}\mathrm{FST} / \mathrm{K}=8.0 \mathrm{KN} / \mathrm{mm} \\
\mathrm{DFF} / \mathrm{K}=15.76 \mathrm{KN} / \mathrm{mm}\end{array}$ & 17.95 & 15.24 & 15.25 & 15.33 & 15.35 & $\begin{array}{c}\text { Maintain } \\
\text { base plate K } \\
\text { value. }\end{array}$ \\
\hline $\begin{array}{c}\mathrm{FST}(\mathrm{K}=8.0 \mathrm{KN} / \mathrm{mm})+ \\
\mathrm{DFF}(\mathrm{K}=25.0 \mathrm{KN} / \mathrm{mm})\end{array}$ & 17.95 & 15.34 & 15.35 & 15.43 & 15.44 & $\begin{array}{c}\text { Increasing } \\
\text { base plate K } \\
\text { value. }\end{array}$ \\
\hline
\end{tabular}


To combine the track parameter with Table 6 that disregards the beam and slab bending wave effect, the rubber stiffness will increase with the load arising, and the damping ratio etc. Taking the single degree of freedom tandem compound into consideration, the calculation coupling with the nature frequency is shown in Table 7.

The system performance frequency under the suggested FST and W1 carload was summarized as Table 8; they will enable to computation anti-vibration value.

Table 6: The frequency under FST and W1 carload on the rail plate $25 \mathrm{KN} / \mathrm{mm})$.

\begin{tabular}{|c|c|c|c|c|c|}
\hline & \multicolumn{5}{|c|}{ W1 load, DM1 or M2 car } \\
\cline { 2 - 6 } & Mass & $\begin{array}{c}\text { Elastic } \\
\text { coefficient }\end{array}$ & $\begin{array}{c}\text { Single freedom } \\
\text { frequency }\end{array}$ & $\begin{array}{c}\text { Couple } \\
\text { frequency }\end{array}$ & $\begin{array}{c}\text { The difference of } \\
\text { frequency }\end{array}$ \\
\hline $\begin{array}{c}\text { Secondary suspension } \\
\text { system (M4、K4) }\end{array}$ & 21820 & 0.83 & 0.98 & 0.87 & $-12.07 \%$ \\
\hline $\begin{array}{c}\text { Main suspension system } \\
\text { (M3、K3) }\end{array}$ & 5847 & 3.27 & 3.77 & 4.13 & $9.57 \%$ \\
\hline Base plate (M2、K2) & 2013 & 200.00 & 50.17 & 60.41 & $20.43 \%$ \\
\hline $\begin{array}{c}\text { FST support bearing } \\
\text { (M1, K1) }\end{array}$ & 5032 & 64.00 & 17.95 & 15.43 & $-14.05 \%$ \\
\hline
\end{tabular}

Note 1: The assumption was the bogie supports by two FST slab(each FST slab long $1.45 \mathrm{~m}$, width $2.8 \mathrm{~m}$, thick $0.25 \mathrm{~m}$ ), with 8 base plate and supporting bearing.

In Table 8, the nature frequency of FST is $15.43 \mathrm{~Hz}$ and the rail base plate nature frequency is $60.41 \mathrm{~Hz}$. Finally, the FST close to the building had to meet the noise and the vibration criterion as follows:

\section{A. Noise:}

The building internal noise of degree the whole a weighting under train causes was no more than 35 decibel (A).

B. Vibration:

The building internal vertical or the Z-axis vibration level at 1 hertz to $80 \mathrm{~Hz}$ $1 / 3$ octave bands s cannot over the ISO 2631-2 datum curve 0.25 multiplication.

The comparison of the acceleration by measurement after completion of the track must be done.

\section{Site measurement}

The transfer mobility measurement was carried on at the slab, the tunnel invert, and the side wall of the FST, trying to check with the theoretical analysis results. 


\subsection{Measurement methods}

The transfer mobility measurement was carried on at three locations inside the tunnel (each location has three sensors installed at the slab, two at the tunnel invert and one the side wall). A hammer was used as the vibration source measured in three stages - without the slab in the first stage, with the slab in the second stage, with the slab and the track in the third stage. The first stage measured the tunnel invert without the slab and tried to screen out the varied influence from the soil; the second stage, which measured the tunnel invert and the slab, was mainly to define the nature frequency of the slab; and the third stage measuring the tunnel invert and the slab with the track was aimed to find out the vibration deduction from the slab to the invert, making sure the FST will meet functional criteria.

\subsection{The results}

It will have some results during the site measurement that will state as follows:

A. The nature frequency of slab will be $18 \mathrm{~Hz}$ in the second stage, and it was $14 \mathrm{~Hz}$ in the third stage. It was all below $18 \mathrm{~Hz}$ that was our prediction. For the narrow bank transfer mobility was from 1 to $80 \mathrm{~Hz}$.

B. The measurement of each location data vertical frequency at $14 \mathrm{~Hz} \pm 4.5 \%$ (horizontal frequency at $11 \mathrm{~Hz} \pm 3.5 \%$ ) is as the following: Form the set out platform to the point.

Table: 7 .

\begin{tabular}{|c|c|c|c|}
\hline & $\begin{array}{c}\text { Location 1 } \\
\text { dBre:1 micro in/lb-sec }\end{array}$ & $\begin{array}{c}\text { Location 2 } \\
\text { dBre:1 micro in/lb-sec }\end{array}$ & $\begin{array}{c}\text { Location 3 } \\
\text { dBre:1 micro } \\
\text { in/lb-sec }\end{array}$ \\
\hline $\begin{array}{c}\text { Measured platform to } \\
\text { slab }\end{array}$ & 73.27 & 74.04 & 74.1 \\
\hline $\begin{array}{c}\text { Measured platform to } \\
\text { invert }\end{array}$ & 31.36 & 33.86 & 33.8 \\
\hline
\end{tabular}

They were all less than $35 \mathrm{db}$ in this stage, we are quite confident that the final measurement inside the reception building will be below $35 \mathrm{db}$.

\section{Conclusion}

In modern technology, the FST is the best anti-vibration solution of the track systems such as high-speed railroad, traditional railroad, urban track transport, and light rail transportation, whenever they need the severe anti-vibration request. However its construction cost was 3-10 times more expensive than common non-ballasted track (according to material difference). Therefore, the FST needs to be analyzed over and over. Its actual results depend on good evaluation, appropriate design, and suitable construction. The above-mentioned studies include the discussion of the analysis, the design, and the preliminary verification stages. 
This paper includes the FST information analyses and the preliminary verification, the analysis and theoretical calculation based on local situation (including the vehicle, civil structure, track.) on the Taipei MRT system. We will continue to study and check the practice results through and after construction stage. Due to high cost, it is impossible to have the study executed by an academic authority. Therefore, it was the first study of FST in Taiwan. The study can be summed up into three conclusions as follows:

A. The geological condition would not be so much impact to the vibration transmission in the same area.

B. The rubber bearing/support will need strict quality control, because it will impact on the static and dynamic stiffness deviation, damping ratio and damping coefficient.

C. The full understanding of the local condition and an appropriate analysis could get the satisfied results.

We would like to share our study results and hope that the data bank will be useful. Also we look forward to receiving valuable ideas from you.

\section{References}

[1] Sy Chang, Kuo H. Cheng, K. Y. Chang, Relon J.T, The study of design on the urban track transportation vibration prevention-Floating Slab Track in the Bored tunnel at Taipei, COMPRAIL 2006.

[2] M. I. Baxter, "Versatile Track Designs Solve HK Airport Line Constraints", Railway Gazette International, Nov. 1998

[3] Birgitta Berglund, Thomas Lindvall and Dietrich H Schwela, "Guidelines for Community Noise", World Health Organization (WHO), 1999

[4] BMTC, "Quantitative Assessment of Groundborne Noise and Vibration", TMI/0110/200/1, Feb. 1987

[5] DORTS, "Transit Noise and Vibration Prediction Methodology and Design Criteria", ATC Study Report No. FE-31, Sep. 1990

[6] J. Eisemann, L. Steinbeisser \& Deischl, "Noise and Vibration Reducing Track Foundation for Subways and Rapid Transit Railways", Track Technology, 1985

[7] ESI Engineering, Inc.,"City of Mankato- DM\&E Vibration Assessment Vibration Impact Expected Through Mankato, Minnesota", ESI Project 1105, Oct. 28, 1999

[8] P. Grootenhuis, "Floating Track Slab Isolation for Railways", Journal of Sound and Vibration (1977) 51 (3), 433-448

[9] Wilson, Ihrig and Associates, "State-of-the-Art Review: Prediction and Control of Groundborne Noise and Vibration from Rail Transit Trains", UMTA, Dec 1983

[10] Mohammad Irshad \& James Haggins, "Ground Borne Noise and Vibration Mitigation Designs”, APTA Rapid Transit Conference, 1994 
[11] ISO 2631-2, "Evaluation of Human Exposure to Whole-Body Vibration Part 2: Continuous and Shock-Induced Vibration in Buildings (1 to 80 $\mathrm{Hz})$ ", 1989

[12] Jakob Laigarrd and Ole Damgarrd Larsen, "Careful Design Minimises Metro Noise and Vibration", Metro Report 2000, Railway Gazette International

[13] Paul J. Remington, Leonard G. Kurzweil \& David A. Towers, "LowFrequency Noise and Vibration from Trains", Transportation Noise Reference Book 